\title{
Audit Committee Financial Expertise and Financial Reporting Timeliness
}

\section{Aimienrovbiye Humphrey Ehigie}

\author{
Accountancy Department, \\ Lighthouse Polytechnic, Sonshine Hills, \\ Km 32 Benin-Asaba, Expressway, \\ Abudu, Nigeria \\ P. A. Isenmilia \\ Accounting Department, \\ University of Benin, P. M. B 1154, \\ Benin City, Nigeria
}

DOI: https://doi.org/10.36941/mjss-2022-0015

\begin{abstract}
This study examines conceptually the relevance of the audit committee financial expertise to financial reporting timeliness of a firm. The methodology adopted in this study is library research whereby relevant and extant literature related to the audit committee financial expertise and financial reporting timeliness. Audit committee financial expertise was $x$-ray from the perspective of accounting financial expertise and the non-accounting financial expertise. Observations from the study highlights that the presence of accounting financial experts in an audit committee is an important element that mitigate reportorial challenges and motivates financial reporting timeliness. The study recommends that financial experts in the audit committee should be given more power to enable them discharge their duty effectively and efficiently, the definition of audit committee financial expertise should not relegate other relevant profession to the background, and the impact of the audit committee financial expertise on audit expectation gap should be considered when appointing members of the audit committee.
\end{abstract}

Keywords: Audit Committee Financial Expertise, Accounting Financial Experts and Non-Accounting Financial Experts

\section{Introduction}

Audit committee delivers efficiently and effectively on its responsibilities when a director with financial expertise is present in the committee (Hashim \& Abdul Rahman, 2010). Audit committee financial expertise is significant in determining the efficient utilisation of time when reporting financial information and it is indicated by functioning as an enforcement tool that enhances the timely financial reporting.

The objective of the study is to examine conceptually the relevance of audit committee financial expertise to financial reporting timeliness. The focus of this study is highlighted in the justification that audit committee is significantly effective and improves the timeliness of financial report. 
However, audit committee financial competency or financial expertise is an (Doyle and Magilke, 2013) utmost determinant of the effectiveness of the audit committee functions which has become the focus of regulatory agencies and standards setting bodies (such as Central Bank of Nigeria, Security and Exchange Commission and Financial Reporting Council of Nigeria). These regulatory actors suggest that improving timeliness of financial reporting is a priority (Abernathy, Barnes, Stefaniak, \& Weisbarth, 2016; Doyle \& Magilke, 2013; Schmidt \&Wilkins, 2013). In addition, audit committee financial expertise enhances the qualitative and quantitative features of financial statements through sound and robust review of the financial report. Furthermore, the expectation that audit committee exercises an active monitoring of the company's financial reporting process is well recognised (Puasa, Fairuz Md Salleh, \& Ahmad, 2014) and this role has been confirmed by most corporate governance codes and professional pronouncements (Song \& Windram, 2004).

It is pertinent to note that prior research have conducted review on audit committee characteristics (such as corporate governance and audit committee independence) that are related to timely financial reporting (Ettredge, Li, \& Sun, 2006) alongside research conducted on the association between audit committee financial expertise and financial reporting timeliness by the following strand of studies such as Aifuwa, Embele, \& Saidu, 2018; Yunos, 2017; Al-Muzaiqer, Ahmad, \& Hamid, 2018; Oraka, Okoye, \& Ezejiofor, 2019; Pradipta \& Zalukhu, 2020; Sultana, Singh, \& Van der Zahn, 2014, consequently, disclosed mixed and inconsistencies in their various findings which have motivated the study. Following the highlights above, this study is motivated to examine the relevance of audit committee expertise to financial reporting timeliness in a firm.

The study is singularly relevant as it conceptually reviews the relationship between audit committee financial expertise and financial reporting timeliness because the audit committee that is in charge of audit is saddled with the responsibility for conducting oversight function on the auditor affairs and engagements (Sarbanes-Oxley Act of 2002) and it is a fundamental basis and a vital aspect of financial reporting timeliness (Leventis, Weetman, \& Caramanis, 2005; Abernathy, Herrmann, Kang, \& Krishnan, 2013).

To ensure the timeliness of financial reporting, the Public Company Accounting Oversight Board (PCAOB) in 2012 established the Statement of Auditing Standard No. 16 (SAS 16) so as to increase and sustain the communications that exist between the external auditors and members of the audit committee (Beest, Braam, \& Boelens, 2009). Audit committee enhances the accounting and internal control system in the company and provide control mechanisms that detects and prevent fraud (Sengupta, 2004). The audit committee report, further provides evidence that the external auditors report on the financial statements was thoroughly reviewed (Lee \& Park, 2018).

This study contributes to the literature in the following ways; one, building on prior studies that examine the relation between audit committee and financial reporting quality, we examine whether audit committee financial expertise is associated with improved financial reporting timeliness. Two, that audit committee financial expertise facilities financial reporting timeliness through the competency of the audit committee members. This study proceeds in the following order; section 2 discusses the financial reporting timeliness. While, section 3 looked at the audit committee financial expertise. Section 4 explains audit committee financial expertise and financial reporting timeliness while section 5 concludes the study.

\section{Financial Reporting Timeliness}

The timeliness of financial report is required to gain investors' confidence (Leventis, et al., 2005). In the emerging capital market, timely audited financial statement may likely be the most reliable (Habib and Bhuiyan, 2010) sources of financial information available in the market (Yunos, 2017). Timeliness of financial reporting is an important qualitative characteristic of financial information (Beest et al., 2009). Timeliness is one out of the several qualitative characteristics of financial statement that determines financial information quality (Al-Muzaiqer, Ahmad, \& Hamid, 2018).

More so, a timely financial information accounting refers to the financial statements that is 
reported on or before the reporting timeline or deadline (Aifuwa, Embele, \& Saidu, 2018; Pradipta \& Zalukhu, 2020). It is expected that timely reporting could mitigate the negativity impact of insider trading activities and help to build a dependable and truthful atmosphere in capital markets (Blankley, Hurtt, \& MacGregor, 2014) and further convey confident signals to stakeholders (Clatworthy \& Peel, 2016). Financial reporting timeliness of accounting information has been distinguished as one of the four characteristics of useful accounting information (IASB 2010). In addition, the FASB (2010) in their conceptual framework described information timeliness as the information that is available to stakeholders for making informed decisions in order not to lose the ability of influencing the decisions (Habib \& Bhuiyan, 2010).

The timely provision of accounting information plays a vital role in firm value (Blankley, Hurtt, \& MacGregor, 2014) thus, financial information is devoid of information asymmetry (Lee, Mande, \& Son, 2009). The quality of earnings reporting is highly enhanced and the likelihood of misleading investors is mitigated through timely financial reporting (Clatworthy \& Peel, 2016).

Timely financial reporting involves the combination of audit related and a firm specific factor (Owusu-Ansah, 200o). Meanwhile, the audit related factors that affect the process of issuing the audit report include audit personnel, transaction volume of the company and competency of the staff (Bushman \& Smith, 2001). On the other hand, firm specific factors that influence management's decision in producing the financial reports are profitability, capital employed, working capital and leverage (Sultana, Singh, \& Van der Zahn, 2014). Financial reporting timeliness has been proxied by audit report lag, earning announcement lag and Securities and Exchange late filing.

Audit report lag is one of the noticeable elements employed by investors and other stakeholders to measure and determine the audit efficiency of audit engagement exercise (Habib \& Bhuiyan, 2010). The date between a company's financial year-end and the audit report date is known as Audit report lag (Sultana et al., 2014). Schmidt \& Wilkins (2013) argued that audit report lag is one of the few externally observable variables that are associated with audit efficiency and it is directly connected with the timeliness of announcements of companies' earnings (Lee, Mande, \& Son, 2009).

However, a long and prolonged audit report lag suggests postponement by management in the release of earnings information to investors and decreases the informational efficiency of markets (Albring, Robinson, \& Robinson, 2014). Audit report lag is a fundamental variable and it is an objective mechanism that measure (Dao \& Pham, 2014) the speed which is involve in the publication of an organisation's audited financial report and recognised among other variables the audit committee capability to follow through the financial report audit processes. According to the Nigeria Exchange Group (2016), in order to increase informational efficiency of the capital market, the Nigeria Exchange Group Limited approved that the audited annual report and financial statements should be submitted to the Exchange within and not exceeding ninety (90) datebook days immediately following the relevant financial year end and the companies must published in not less than two (2) countrywide day-to-day newspapers within and not exceeding ninety twenty-one (21) datebook days before the official date of the company's Annual General Meeting, and reportorial must be extended and paste on the company's official internet site and the web address released in the newspaper publications (Baatwah, Ahmad, \& Salleh, 2013).

Sultana, et al. (2014) affirm by supporting the view that there is a significant negative association between audit committee financial expertise and audit report lag. There is, therefore a further point which was stressed in their study that the members of audit committee with financial expertise and independent of management influence have the likelihood of increasing audit committee effectiveness and significantly reduce the time taken for the auditor to issue the audit report. Sultana et al. (2014) reported no relationship between audit report lag and audit firm size, meeting frequency and audit committee gender diversity. Schmidt and Wilkins (2013) predicted that audit committee that has large number of accounting and financial experts are fundamentally efficient and effective in timely financial reporting. Afify (2009) averred that audit committee financial expertise has significant effect on the audit report lag. (Leventis, et al., 2005) disclosed that there is an association between the type of audit firm and audit report lag. International audit firms were found to be highly 
associated with the timeliness of financial reporting (Leventis, et al., 2005).

Earnings announcement lag (EAL) is a fundamental measure and it involves the organisation's decision and ability to release earnings information which is a reflection of an internal confidence on the organisation's accounting and internal control systems that produces the financial report that is reviewed by the audit committee and management (Behn, Sercy, \& Woodroof, 2006; Clatworthy \& Peel, 2016; Doyle \& Magilke, 2013; Schmidt \& Wilkins, 2013; Sultana, et al., 2014). In addition, the timely release of earnings report triggers a rapid response from the capital market (Afify, 2009) and it is pertinent to indicate that large number of financial information reaches the capital market within the financial year when earnings reports are released within the regulated time than at any other times (McTague, 2002). For instance, in Nigeria, the Federal Inland Revenue Service (FIRS) provides that companies should file their annual financial statements not later than six (6) months after the company's financial year end and it has apparently observed that the revenue service receives more financial information within the periods of January to June which is the deadline for most companies whose financial year ends in December.

Security and Exchange Commission late filing also measures timelines of financial reporting because when organisations delayed the filing of financial statements with the SEC, it can create a negative market adjusted stock returns and other consequences (Liu, Jaikaeo, Shen, \& Hwang 20o9).

\section{Audit Committee Financial Expertise}

Audit Committee is a board committee that is assigned to review the audit engagement processes and enhance timely and quality annual financial statements by conducting oversight and monitoring functions on the financial reporting processes (Sultana, Singh, \& Van der Zahn, 2014). The Nigeria code of corporate governance (2018) highlights the responsibilities of the audit committee. The committee conducts a very vital role in the monitoring of financial reporting processes and procedures in line with the Companies and Allied Matters Act, 1990 as amended 2020. Interestingly, the audit committee is expected to be independent which means the committee should be unbiased in executing its responsibilities (Hashim \& Abdul Rahman, 2011).

Financial expertise is the competency possess by an individual who has acquired the accounting and finance qualifications that enables him/her to perform the duties of a finance experts (Albring, et al., 2014). The definition of financial expertise has been further classified into broad and narrow definitions (Schmidt \& Wilkins, 2013; Abernathy, Barnes, Stefaniak, \& Weisbarth (2016). The broad definition expands the requirements of a financial expert beyond the narrow definition's scope. The narrow definition of financial expertise views accounting financial expert and non-accounting financial experts differently (Sultana, 2014).

Therefore, the accounting financial experts (AFEs) are persons that acquire accounting expertise through studying accounting in a formal education setting as well as garnering work experiences in auditing and accounting workplaces (Albring, Robinson, \& Robinson, 2014), however, the nonaccounting financial experts (AFEs) are individual that have only work experience in finance related positions and other positions that oversee the finance director or that the finance director reports to directly these finance experts include those that acquire work experiences by holding a finance portfolio, the company's president or chief executive officer (Choi, Han, \& Lee (2014); Schmidt \& Wilkins, 2013). However, it is apparently obvious that the broad definition of financial expertise captured both the accounting financial experts and the non-accounting financial experts, consequently the AFEs and non-AFEs were not differentiated (Badolato, Donelson, \& Ege, 2014; Farber (2005); Carcello, Hollingsworth, Klein, \& Neal (2006).

Abernathy, Beyer, Masli, and Chad (2014) advocates that the presence of financial experts on audit committees increases the effectiveness and efficiency of the audit committee members in monitoring financial reporting quality and timeliness (Abbott, Parker, \& Peters, 2004). Therefore, section 407 of the Sarbanes Oxley Act, 2002, requires the Securities and Exchange Commission (SEC) to adopt rules and regulations which mandates and provides that the audit committees of public 
limited companies or listed companies must have at least one member who is a financial expert (Abernathy, et al. 2014) or they are expected to provide disclosure for non-compliance with the adoption of this requirements. Specifically, the SEC originally provided a strict financial expertise definition stating that it involves an individual who has studied accounting or experienced in accounting or auditing such as auditor, Chief Financial Officer, Financial Controller or accounting officer (DeZoort \& Salterio, 2001; Davidson, Xie, \& Xu (2004). This definition was criticised as being that the definition was apparently too restrictive. While SEC (2002) obviously and absolutely adopts the audit committee financial expertise definition that captured the AFEs and the non AFEs as qualifications for audit committee membership (Yunos (2017); Krishnan \& Lee (2009). In order words, SEC supported the broad scope definition of the audit committee financial expertise and mentioned that members of audit committee are recognised (Agrawal \& Chadha, 2005) and designated as financial expert if the members either have accounting competency (such as accounting officer, Chief Finance Officer, Financial Controller or Auditor) or accounting professional qualification or the members are non-accounting financial experts with other different qualifications (such as Company's President, business financial analyst, Investment bankers or Chief Executive Officer) (Krishnan \& Visvanathan, 2008). Consequently, in accordance with the broad definition the recognised members with financial expertise that should be in the audit committee comprise of the accounting financial experts (AFE) and the non-financial accounting expert (non-AFE) (Anderson, Mansi, \& Reeb, 2004).

For the purpose of this study, the study adopts a narrow definition of financial expertise which suggest that directors with accounting competency (such as accounting officer, Chief Finance Officer, Financial Controller or Auditor) or accounting professional qualification and have been supported by previous studies (such as Badolato, Donelson, \& Ege, 2014; Dhaliwal, Naiker, \& Navissi, 2010; Hoitash, Hoitash, \& Bedard, 2009; Krishnan \& Visvanathan, 2008) reported that the narrow definition is more effective and better expresses the meaning of financial expertise. Also, they disclosed that the narrow definition of financial expertise describes financial experts that affects the timeliness of financial statements (Mohamad-Nor, Shafie, \& Wan-Hussin, 2010).

In addition, DeFond, Hann, and $\mathrm{Hu}(2005)$ posit and hold the view that accounting financial expert may be more relevant for performing functions and tasks that demand high level of accounting intelligence and techniques. Similarly, Beasley, Carcello, Hermanson, and Neal (2009) and Hoitash, et al. (2009) were of the view that audit committees accounting financial experts concerned with the accounting assumption, estimates and judgments that are inherent in the Generally Accepted Accounting Principles (GAAP) and the entire audit processes. In another perspective, Cohen, Krishnamoorthy and Wright (2008) contend that specific and direct accounting experience and skills improve audit committee members' efficiency and capacity to grasp and deal with the technical issues and challenges facing their companies financially.

The Nigeria Code of Corporate Governance (2018) issued by the Financial Reporting Council of Nigeria (FRCN) states that all members of the committee should be financially literate and should be able to read and understand financial statements. It also stated that at a minimum number of one financial expert should be a member of the company's audit committee and must have knowledge in accounting and financial management in order to be fully equipped with the skills and ability to interpret the company's financial statements. Also, the code further mention that private companies should ensure that members in the committee in charge of audit should include the non-executive directors (NEDs) and most of the members should be independent non-executive (INEDs) (Hashim \& Abdul Rahman, 2011). The code further explained that in the case of the statutory audit committee, a chairman should be elected from amongst its members, and should have financial literacy and the audit committee meeting should be at least once every quarter. In order words, the audit committee is expected to meet four (4) times in one financial year and within these periods all financial matters affecting the accounting and internal control systems are addressed and to eliminate the bottlenecks that would have resulted in audit delays (Abernathy, Herrmann, Kang, \& Krishnan, 2013). 


\subsection{Accounting and Non-Accounting Financial Expertise}

The study of Bilal, Chen, \& Komal (2018) disclosed that there is a continuous debate in literature on the most influential in enhancing financial reporting timeliness between accounting financial expert and the non-accounting expert. Prior studies (such as Carcello, et al., 20o6; Kusnadi, Leong, Suwardy, \& Wang (2014); Nelson \& Devi, 2013) discovered accounting financial experts and non-accounting financial expert are effective in enhancing financial reporting timeliness. Contrarily, the studies of Dhaliwal et al. (2010) and Krishnan \& Visvanathan (2008) supports that accounting financial experts are more effective in enhancing financial reporting timeline.

It is relevant to note that agency theory requires a company's audit committee to reduce agency costs through the oversight functions it exercises on the corporate financial reporting processes and improves the financial statement quality (Archambeault, DeZoort, \& Hermanson, 2008). Further, the existing and relevant strand of literature emphasises on the accounting financial experts and posits that these experts are capable of enhancing effective monitoring of the financial reporting processes through their competency and technical knowledge in the fields of accounting and auditing. In another perspective, the resource dependent asserts that the non-accounting financial experts who possess financial and supervisory experience can considerably enhance the effectiveness of audit committee by providing industry and business knowledge. It stresses further that the non-accounting financial experts may not possess specialized accounting qualifications, they have valuable understanding of financial and non-financial aspect of financial reporting. This enhances their knowledge to provide judgment on the reasonability of accounting procedures whenever their firm is exposed to business, industry and regulatory risk (Sultana \& Zahn, 2015).

Studies such as (Carcello, et al., 2006; Krishnan \& Visvanathan, 2008) support the view that financial experts with accounting expertise are more effective in an audit committee's monitoring role. Interestingly, members of audit committee are charged with responsibilities and tasks that involve complex and challenging accounting issues in which members with sophisticated training and accounting expertise may be more relevant than the non-accounting experts who the possess such expertise (DeFond, Hann, \& Hu, 2005). DeZoort and Salterio (2001) underscore that most audit committee members consider that accounting financial expertise is vital and critical for the committee to effective in the discharge of its deliverables. Indeed, this study support the position that accounting financial expert is better since they possess specialised accounting qualifications and more sophisticated knowledge than the non-accounting financial expert.

\section{Audit Committee Financial Expertise and Timeliness of Financial Reporting}

Prior studies (such as Farber, 2005; Abernathy, Herrmann, Kang, \& Krishnan, 2013; Che Ahmad \& Abidin, 2008; Hashim \& Abdul Rahman, 2010; Mohamad-Nor, Shafie, \& Wan-Hussin, 2010; Shukeri \& Islam, 2012) have found mixed results on the relationship between audit committee characteristics and timeliness of financial reporting. Meanwhile, it therefore indicates that the studies above could not identify the effect of the presence of an accounting financial expert or non-accounting financial expert in an audit committee on the financial reporting timeliness.

Researchers (such as Albring, Robinson, \& Robinson, 2014; Cohen, Krishnamoorthy, \& Wright, 2004) in their various studies decomposed audit committee financial expertise into accounting financial experts and it further revealed and suggested therefore, that where the financial expert is included in the audit committee there is a positive association between the audit committee effectiveness and timely financial reporting. In another point, Dhaliwal, Naiker, and Navissi (2010) in their study used accounting financial expert as a variable for audit committee financial expertise, they discovered that there is no association between audit committee financial expertise and the timeliness of financial statement and therefore emphasised that there is an unconcluded debate on what makes up the financial expertise.

In other studies (such as DeFond, Hann, \& Hu, 2005; Krishnan \& Visvanathan, 2008) their study 
represented audit committee financial expertise with accounting financial expert and they provide that having accounting financial experts on the audit committee shows positive association with financial reporting timeliness. The studies of DeZoort and Salterio (2001) and McDaniel, Martin, and Maines (2002) averred that financial expertise impacts audit committee members' judgments and financial reporting-related outcomes. Mustafa and Youssef (2010) suggested that each group (that is accounting financial experts and non-accounting financial experts) may bring different perspectives to audit committee meetings and thereby improve financial reporting timeliness. They find that higher percentage of financial experts in the audit committee may likely reduce assets misappropriation in the company, specifically, they lend their voice to support the broad definition of financial expertise.

Specifically, studies (such as DeFond, Hann, and Hu, 2005) disclose that the capital market encourages discrimination between accounting financial experts and non-accounting financial experts on the audit committee. This therefore means that the market supports and rewards companies where financial experts are appointed as board members who in turned form parts of the members of audit committee when compared with companies that appoints company's directors using the criterion of non-accounting financial experts into the audit committee of the board. In addition, the study of Abernathy, Beyer, Masli, and Chad (2014) lend its voice to support the position of the Security and Exchange Commission (SEC)'s authentic narrow definition of the financial expertise and its mandatory requirement of including an accounting financial expert in the audit committee. They emphasised that the application of the narrow definition of accounting financial expert implies apparently that only the director with accounting financial expertise is appointed in the audit committee and this further enhances corporate governance.

\subsection{Weakness of Audit Committee Financial Expertise}

The study posits that one of the weaknesses of the audit committee financial expertise is that the power of the financial experts in the audit committee is limited and insufficient for them to discharge their responsibilities as more of the power is concentrated in the audit committee chair and this therefore makes them play advisory function (Baatwah, Ahmad, \& Salleh, 2013). The audit committee chair holds the major power and direct the day-to-day affairs of the audit committee.

The regulators have not provided standards or guidelines that will support the advisory role of the financial experts. Further, the narrow definition of financial expertise played down the role of other expertise (non-accounting and financial expertise) whose input contributes largely to timely financial reporting (Dhaliwal et al., 2010). Another weakness of audit committee financial expertise shows that the audit expectation gap was not put into consideration when providing the broad definition of audit committee financial expertise which refers the financial experts as accounting financial experts and non-accounting financial experts (Bilal, Chen, \& Komal, 2018).

\section{Conclusion}

The study examines conceptually the relevance of audit committee financial expertise to financial reporting timeliness. The study reviewed audit committee financial expertise in terms of the presence of accounting financial experts and the non-accounting financial experts in the audit committee. Also, audit committee financial expertise is particularly relevant because recent regulatory actions suggest that improving timeliness of financial reporting is a priority for regulators. It is vital to highlight that it is not the existence of the audit committee in itself that enhances financial reporting timeliness but its monitoring effectiveness and competencies that impact significantly on the organisation. Audit committee financial expertise is significant that it reduces audit report lag, delay in the announcement of earnings and late filings with regulators. The study supports the narrow definition of audit committee financial expertise haven observed that the presence of accounting financial experts in the audit committee facilitates the timely financial reporting by eliminating the 
audit report lag.

However, audit committee financial expertise is relevant to the timeliness of financial reporting since it provides informational efficiency and removes the delay in the announcement of the company's earnings. The study further observed that accounting financial experts provide technical competence that enhances audit committee effectiveness and reduces the number of hours required to adequately and sufficiently discuss, comprehend and ascertain relevant accounting and financial issues with management and external auditor. The observation of the study is consistent with the studies of Abbott, et al. (2004) and Cohen, et al. (2004), therefore, the presence of a financial expert on the audit committee enhances the effective monitoring financial reporting timeliness.

The study recommends that financial experts in the audit committee should be given more power to enable them discharge their duty effectively and efficiently, the definition should not relegate other relevant profession to the background, and the impact of the audit committee financial expertise on audit expectation gap should be considered when appointing members of the audit committee.

\section{References}

Abbott, L. J., Parker, S., \& Peters, G. F. (2004). Audit committee characteristics and restatements. A Journal of Practice and Theory, 23(1), 69-87.

Abernathy, J. L., Barnes, M., Stefaniak, C., \& Weisbarth, A. (2016). An international perspective on audit report lag: A synthesis of the literature and opportunities for future research. International Journal of Auditing, 21(1), 100-127. doi:10.1111/ijau.12083

Abernathy, J. L., Beyer, B., Masli, A., \& Chad, S. (2014). The association between characteristics of audit committee accounting experts, audit committee chairs, and financial reporting timeliness, Advances in Accounting, incorporating Advances in International Accounting, 1 - 15. http://dx.doi.org/10.1016/j.adiac.2014.09.001.

Abernathy, J. L., Herrmann, D., Kang, T., \& Krishnan, G. V. (2013). Audit committee financial expertise and properties of analyst earnings forecasts. Advances in Accounting, 29(1), 1-11. doi:10.1016/j.adiac.2012.12.001

Afify, H. A. E. (2009). Determinants of audit report lag. Journal of Applied Accounting Research, $10(1), 56-86$. doi:10.1108/o9675420910963397

Agrawal, A., \& Chadha, S. (2005). Corporate governance and accounting scandals. Journal of Law and Economics, 48, 371-406.

Albring, S., Robinson, D., \& Robinson, M. (2014). Audit committee financial expertise, corporate governance, and the voluntary switch from auditor-provided to non-auditor-provided tax services. Advances in Accounting, 30(1), 81-94. doi:10.1016/j.adiac.2013.12.007

Aifuwa, H. O., Embele, K., \& Saidu, M. (2018). Ethical accounting practices and financial reporting quality. EPRA International Journal of Multidisciplinary Research, 4(12), 31-44

Al-Muzaiqer, A. H., Ahmad, M., \& Hamid, F. A. (2018). Timeliness of financial reporting and audit committee effectiveness: Evidence from UAE. Review of Accounting and Finance, 1(1), 99-112.

Anderson, R. C., Mansi, S. A., \& Reeb, D. M. (2004). Board characteristics, accounting report integrity, and the cost of debt. Journal of Accounting and Economics, 37, 315-342.

Archambeault, D. S., DeZoort, F. T., \& Hermanson, D. R. (2008). Audit committee incentive compensation and accounting restatements. Contemporary Accounting Research, 25(4), 965-992.

Baatwah, S. R., Ahmad N., \& Salleh, Z. (2013). Audit committee financial expertise and financial reporting timeliness in emerging market: Does audit committee chair matter? Issues in Social and Environmental Accounting, (10) $4,63-85$.

Badolato, P. G., Donelson, D. C., \& Ege, M. (2014). Audit committee financial expertise and earnings management: The role of status. Journal of Accounting and Economics, 58(2-3), 208-230. doi:10.1016/j.jacceco.2014.08.006.

Beest, F. V., Braam, G., \& Boelens, S. (2009). Quality of financial reporting: measuring qualitative characteristics. NiCE Working Paper, 9(108): 1-41.

Beasley, M. S., Carcello, J. V., Hermanson, D. R., \& Neal, T. L. (2009). The audit committee oversight process. Contemporary Accounting Research, 26(1), 65-122. doi:10.1506/car.26.1.3

Behn, B. K., Searcy, D. L., \& Woodroof, J. B., (2006). A within-firm analysis of current and expected future audit lag determinants. Journal of Information Systems, 20(1), 65-86.

Bilal, R, Chen, S., \& Komal, B. (2018). Audit committee financial expertise and earnings quality: A meta-analysis. Journal of Business Research, 84, 253-270. doi:10.1016/j.jbusres.2017.11.048 
Blankley, A. I., Hurtt, D. N., \& MacGregor, J. E., (2014). The relationship between audit report lags and future restatements. Auditing: A Journal of Practice and Theory, 33(2), 27-57.

Bushman, R. M., \& Smith, A. J., (2001). Financial accounting information and corporate governance. Journal of Accounting and Economics, 32(1), 237-333.

Carcello, J. V., Hollingsworth, C. W., Klein, A., \& Neal, T. L. (2006). Audit committee financial expertise, competing corporate governance mechanisms, and earnings management. Governance $\mathcal{E}$ Internal Control Systems. 1-53. DOI:10.2139/ssrn.887512.

Che-Ahmad, A., \& Abidin, S. (2008). Audit delay of listed companies: A case of Malaysia. International Business Research, 1(4). $1-8$.

Choi, Y. K., Han, S. H., \& Lee, S. (2014). Audit committees, corporate governance, and shareholder wealth: Evidence from Korea. Journal of Accounting and Public Policy, 33(5), 470-489. https://doi.org/10.1016/j.jaccpubpol.2014.06.0o1

Clatworthy, M. A., \& Peel, M. J., (2016). The timeliness of UK private company financial reporting: regulatory and economic influences, British Accounting Review, 48, 293- 315

Cohen, J., Krishnamoorthy, G., \& Wright, A. M. (2004). The corporate governance mosaic and financial reporting quality. Journal of Accounting Literature, 23(1), 87-152.

Cohen, J., Krishnamoorthy, G., \& Wright, A. M. (2008). Form versus substance: The implications for auditing practice and research of alternative perspectives on corporate governance. A Journal of Practice $\mathcal{E}$ Theory, $27(2), 181-198$.

Dao, M., \& Pham, T. (2014). Audit tenure, auditor specialization and audit report lag. Managerial Auditing Journal, 29(6), 490-512. doi:10.1108/maj-07-2013-0906

Davidson, W. N., Xie, B., \& Xu, W. (2004). Market reaction to voluntary announcements of audit committee appointments: The effect of financial expertise. Journal of Accounting and Public Policy, 23(4), 279-293. doi:10.1016/j.jaccpubpol.2004.06.001

DeFond, M. L., Hann, R. N., \& Hu, X. (2005). Does the market value financial expertise on audit committees of board of directors? Journal of Accounting Research, 43(2), 153-193.

DeZoort, F. T. \& Salterio, S. (2001). The effects of corporate governance experience and financial reporting and audit knowledge of audit committee members' judgment, A Journal of Practice $\mathcal{E}$ Theory, 2o(2), 31-47.

Dhaliwal, D., Naiker, V., \& Navissi, F. (2010). The association between accruals quality and the characteristics of accounting experts and mix of expertise on audit committees. Contemporary Accounting Research, 27(3), $787-827$.

Doyle, J. T., \& Magilke, M. J. (2013). Decision usefulness and accelerated filing deadlines. Journal of Accounting Research, 51(3), 549-581.

Ettredge, M., Li, C., \& Sun, L. (2006). The impact of SOX section 404 internal control quality assessment on audit delay in the SOX era. Auditing: A Journal of Practice and Theory, 25(2), 1-23.

Farber, D. (2005). Restoring trust after fraud: Does corporate governance matter. The Accounting Review, 8o(2), 539-561.

Financial Accounting Standard Board (2010). Conceptual framework.

Hashim, U. J. \& Abdul Rahman, R. (2011). Board independence, board diligence, board expertise and impact on audit report lag in Malaysian market. Finance and corporate governance conference 2011. Organised by La Trobe University, Auckland University of Technology, Queensland University of Technology, Victoria University of Wellington \& the Australian Centre for Financial Studies, Melbourne, Australia, 28 - 29 April 2011.

Habib, A., \& Bhuiyan, M. B. U. (2010). Audit firm industry specialization and the audit report lag. Journal of International Accounting, Auditing and Taxation, 20(1), 32-44. doi:10.1016/j.intaccaudtax.2010.12.004

Hoitash, U., Hoitash, R., \& Bedard, J. C. (2009). Corporate governance and internal control over financial reporting: a comparison of regulatory regimes. The Accounting Review, 84(3), 839-867. doi:10.2308/accr.2009.84.3.839

Krishnan, G. V., \& Visvanathan, G. (2008). Was Arthur Andersen different? Further evidence on earnings management by clients of Arthur Andersen. International Journal of Disclosure and Governance, 5(1), 36-47. doi:10.1057/palgrave.jdg.2050072

Krishnan, J., \& Lee, J. E. (2009). Audit committee financial expertise, litigation risk, and corporate governance. A Journal of Practice E Theory, 28(1), 241-261.doi:10.2308/aud.2009.28.1.241

Kusnadi, Y., Leong, K. S., Suwardy, T., \& Wang, J. (2014). Audit committees and financial reporting quality in Singapore. Journal of Business Ethics, 1-18.

Lee, H. Y., Mande, V., \& Son, M. (2009). Do lengthy auditor tenure and the provision of non-audit services by the external auditor reduce audit report lags. International Journal of Auditing, 13(2), 87-104. 
Lee, J., \& Park, J. (2018). The impact of audit committee financial expertise on management discussion and analysis (MD\&A) tone. European Accounting Review, 1-22. doi:10.1080/o9638180.2018.1447387

Leventis, S., Weetman, P., \& Caramanis, C. (2005). Determinants of audit report lag: Some evidence from the Athens Stock Exchange. International Journal of Auditing, 9(1), 45-58. doi:10.1111/j.1099-1123.2005.00101.x

Liu, D. K., Jaikae, C., Shen C. C. \& Hwang, R. H. (2009). Discovering timely information in Manets, Journal among Malaysian Listed Companies. 57(11): 1808-1821.

McDaniel, L. S., Martin, R. D. \& Maines, L. A. (2002). Evaluating financial reporting quality: the effects of financial expertise vs. financial literacy, The Accounting Review, 77( 4), 39-67.

McTague, R. (2002). Sarbanes-Oxley raises liability issues for audit committees, Milstein says. BNA Daily Tax Report.

Mohamad-Nor, M. N., Shafie R. \& Wan-Hussin, W. N. (2010). Corporate governance and audit report lag in Malaysia, Asian Academy of Management Journal of Accounting and Finance, 6(2): 57-84.

Mustafa, S. T., \& Youssef, B. N. (2010). Audit committee financial expertise and misappropriation of assets. Managerial Auditing Journal, 25(3), 208-225. doi:10.1108/02686901011026323

Nelson, S. P., \& Devi, S. (2013). Audit committee experts and earnings quality. The International Journal of Business in Society, 13(4), 335-351.

Oraka, A. O., Okoye, J. A., \& Ezejiofor, R, A. (2019). Determinants of financial reporting timeliness: An empirical study of Nigerian deposit money banks. International Journal of Advanced Academic Research, 5(9), 18-35.

Owusu-Ansah, S., (2000). Timeliness of corporate financial reporting in emerging capital markets: empirical evidence from the Zimbabwe Stock Exchange, Accounting and Business Research, 30(3). 241-254.

Pradipta, A., \& Zalukhu, A. G. (2020). Audit report lag: specialized auditor and corporate governance. GATR Global Journal of Business and Social Science Review, 8(1) $41-48$.

Public Company Accounting Oversight Board (PCAOB) (2012, August). Auditing Standard No. 16. Communications with Audit Committees. Washington, DC: PCAOB.

Puasa, S., Fairuz Md Salleh, M., \& Ahmad, A. (2014). Audit committee and timeliness of financial reporting: Malaysian public listed companies. Middle East Journal of Scientific Research, 22 (2), 162-175. doi:10.5829/idosi.mejsr.2014.22.02.21886

Sarbanes-Oxley Act (2002). Section 406 and 407.

Schmidt, J., \& Wilkins, M. S. (2013). Bringing darkness to light: The influence of auditor quality and audit committee expertise on the timeliness of financial statement restatement disclosures. Auditing: A Journal of Practice E Theory, 32(1), 221-244.

Sengupta, P. (2004). Disclosure timing: Determinants of quarterly earnings release dates. Journal of Accounting and Public Policy, 23(6), 457-482.

Securities and Exchange Commission (SEC) (2002). Proposed rule: Disclosure required by sections 404, 406 and 407 of the Sarbanes-Oxley Act of 2002. Release Nos. 33-8138; 34-46701.

Shukeri, S. N. \& Islam, M. A. (2012). The determinants of audit timeliness: Evidence from Malaysia, Journal of Applied Sciences Research, 8(7), 3314-3322.

Song, J. \& Windram, B. (2004). Benchmarking audit committee effectiveness in financial reporting. International Journal of Auditing, (8), 195-205.

Sultana, N., Singh, H., \& Van der Zahn, J.-L. W. M. (2014). Audit committee characteristics and audit report lag. International Journal of Auditing, 19(2), 72-87. doi:10.1111/ijau.12033

Sultana, N., \& Zahn, V. D. (2015). Earnings conservatism and audit committee financial expertise. Accounting $\mathcal{E}$ Finance, 55(1), 279-310.

The Nigeria Stock Exchange Group (2016). Rulebook, 1 - 7. Retrieved from http://www.nse.com.ng/regula tionsite/IssuersRules/Rules\%20on\%2oFiling\%20of\%20Accounts\%2oand\%2oTreatment\%20of\%2oDefault\% 2oFilings.pdf. February $22^{\text {nd }}$, 2021.

Yunos, R. M. (2017). The relevance of internal governance mechanisms to financial reports timeliness. Management \& Accounting Review, 16(1), 213-234. 